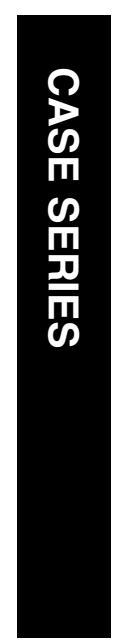

${ }^{1}$ Department of Ophthalmology and Visual Sciences, Alexandra Hospital, Singapore, Singapore

${ }^{2}$ Eye Clinic, Jurong Medical Centre, Singapore,

Singapore

${ }^{3}$ Department of Ophthalmology, Yong Loo Lin School of Medicine, National University of Singapore, Singapore, Singapore

${ }^{4}$ Singapore Eye Research Institute, Singapore,

Singapore

${ }^{5}$ Department of Ophthalmology, Tan Tock Seng Hospital, Singapore, Singapore

Correspondence: S Sanjay, Department of Ophthalmology and Visual Sciences,

Alexandra Hospital, 378, Alexandra Road, Singapore 159964

Tel: + 6563793741 ;

Fax: + 6563793618 .

E-mail: Sanjay_S@

alexhosp.com.sg

Received: 27 December 2007

Accepted in revised form: 11 February 2008

Published online: 14 March 2008

\title{
Optic neuropathy associated with dengue fever
}

\begin{abstract}
Purpose To report a case series of three patients of optic neuropathy associated with dengue fever.

Methods Observational case series. Results Three patients aged of 19, 31, and 40 years (cases 1, 2, and 3) complained of unilateral blurring of vision within a week of being diagnosed with dengue fever. Their presenting visual acuities were counting fingers in cases 1 and 2, and 6/6 in case 3, with features suggestive of optic neuropathy. Two of the three patients (cases 2 and 3) had bilateral ocular signs. The visual acuity recovered to $6 / 9$ in case 1 , worsened to no light perception in case 2 , and remained unchanged in case 3.

Conclusions Although spontaneous visual recovery is possible, optic neuropathy associated with dengue fever may result in severe and permanent visual loss.
\end{abstract}

Eye (2008) 22, 722-724; doi:10.1038/eye.2008.64; published online 14 March 2008

Keywords: dengue fever; ocular manifestations; optic neuropathy; visual loss

\section{Introduction}

Ocular manifestations of dengue fever (DF) are uncommon and may include retinal haemorrhage, cotton wool spot, retinal oedema, and retinal vasculitis/sheathing. ${ }^{1}$ Optic neuropathy associated with DF is even rarer. We report three clinically and serologically $(\operatorname{IgM})$ confirmed DF patients to highlight this unusual complication.

\section{Case 1}

A 19-year-old Chinese woman presented to her local ophthalmologist with blurring of vision in
S Sanjay ${ }^{1,2}$, AM Wagle ${ }^{1,2}$ and KG Au Eong ${ }^{1,2,3,4,5}$

her left eye 5 days after she was diagnosed to have DF. She had a visual acuity of counting fingers, impaired colour vision, optic disc swelling, and retinal oedema in the left eye. She was diagnosed to have optic neuropathy and was treated conservatively.

Three months later, she sought a second opinion from us for persistent impaired vision in her left eye. By this time, her visual acuity had improved to $6 / 9$ in the left eye with a relative afferent pupillary defect, impaired colour vision, and paracentral scotoma with a normal fundus examination. The right eye was normal. Multifocal electroretinography disclosed a centrocaecal scotoma and pattern visual evoked potential ( $\mathrm{pVEP}$ ) revealed a delayed P100 latency in the left eye suggestive of retinal and concurrent optic nerve dysfunction in the left eye. At her last follow-up 10 months following her DF, she had a visual acuity of $6 / 9$, persistent impaired colour vision, and a paracentral scotoma in the left eye.

Case 2

A 31-year-old Malay man presented with decreased vision in his right eye 1 week after he was diagnosed with DF. His visual acuity was counting fingers in the right eye and $6 / 6$ in the left. Fundus examination disclosed a cotton wool spots and retinal haemorrhage adjacent to fovea in both eyes. The optic disc appeared normal in both eyes. A diagnosis of right retrobulbar optic neuritis and bilateral maculopathy was made.

The patient's vision in the right eye worsened the following day to no light perception with a relative afferent pupillary defect. In view of the profound visual loss, he was treated empirically with intravenous methylprednisolone $1 \mathrm{~g}$ for 3 days followed by oral prednisolone $1 \mathrm{mg} / \mathrm{kg}$ body weight for 11 days. Visual field examination could not be done in the right eye but showed an enlarged blind spot in the left eye. 

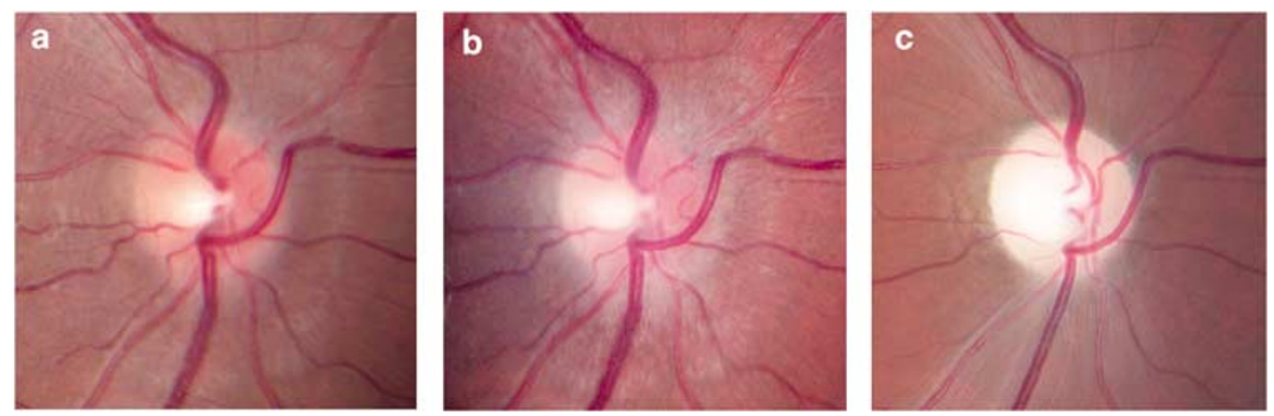

Figure 1 Serial photographs of the right eye in case 2 showing optic disc swelling 3 (a) and 7 (b) days after onset of dengue fever. Optic atrophy is evident 1 month later (c).
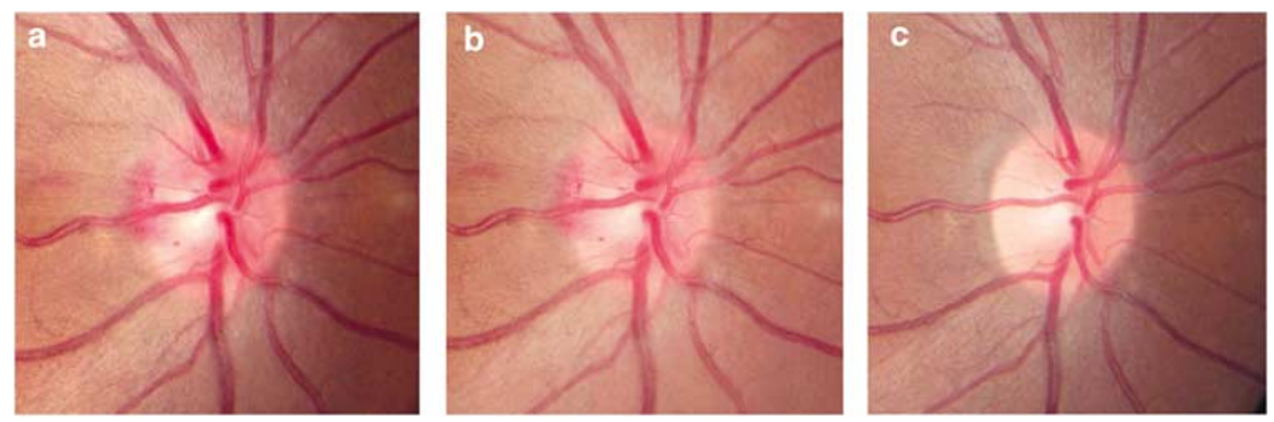

Figure 2 Serial photographs of the right eye in case 3 showing the optic disc 1 (a), 7 (b), and 20 (c) days after onset of dengue fever.

Three days after presentation, optic disc swelling developed in the right eye (Figure 1) and magnetic resonance imaging demonstrated oedema of the optic nerve sheath complex. Pattern electroretinogram revealed a reduced N95:P50 ratio, with no observable response on $\mathrm{pVEP}$ in the right eye suggesting severe optic nerve dysfunction. One month later, optic atrophy was seen in the right eye (Figure 1).

The patient's vision in the right eye remained at no light perception 1 year later. This is probably the only case reported in the literature to have developed blindness following DF associated optic neuropathy. The visual field defects in the left eye, however, recovered completely.

\section{Case 3}

A 40-year-old Chinese woman presented with blurring of vision in her right eye 5 days after she was diagnosed with DF. Her visual acuity was $6 / 6$ with impaired colour vision in both eyes. Fundus examination disclosed bilateral optic disc oedema with splinter haemorrhages (worse in the right eye), retinal haemorrhages, and cotton wool spots in the macula (Figure 2).
Visual field examination revealed a central scotoma in the right eye and paracentral defects in the left eye. The patient declined electrophysiologic tests.

At her last follow-up 6 weeks later, her visual acuity remained $6 / 6$ bilaterally, colour vision and visual fields were normal, optic disc swelling and haemorrhages had resolved completely.

\section{Discussion}

Although rare, $\mathrm{DF}$ is known to be associated with a variety of ophthalmic manifestations. ${ }^{1-12}$ Optic neuropathy associated with DF is extremely rare and three previously published reports are summarised in Table $1 .^{2-4}$ In a recent retrospective series of 41 patients with DF-associated maculopathy, 8 eyes were reported to have disc oedema and 10 eyes had disc hyperaemia. ${ }^{5}$

Optic neuropathy associated with DF is often bilateral. All three previously reported cases had bilateral involvement. ${ }^{2-4}$ Although all three patients in our series presented with unilateral visual symptoms, two of them had bilateral involvement. In addition, concurrent macular involvement is common. Two of the three previously reported patients and all patients in this series had concurrent macular signs. ${ }^{3,4}$ 
Table 1 Summary of published reports of dengue fever associated optic neuropathy

\begin{tabular}{|c|c|c|c|c|c|c|c|}
\hline Author(s) & $\begin{array}{l}\text { Age } \\
\text { (years) }\end{array}$ & Sex & $\begin{array}{l}\text { Visual acuity at } \\
\text { initial } \\
\text { presentation }\end{array}$ & Fundus findings & Intervention & Follow up & $\begin{array}{l}\text { Vision at final } \\
\text { follow-up }\end{array}$ \\
\hline Wen $e t a l^{2}$ & $\begin{array}{l}\text { Not } \\
\text { reported }\end{array}$ & $\begin{array}{l}\text { Not } \\
\text { reported }\end{array}$ & $\begin{array}{l}\text { Perception of } \\
\text { light in both } \\
\text { eyes }\end{array}$ & $\begin{array}{l}\text { Disc oedema in } \\
\text { both eyes }\end{array}$ & High-dose steroids & $\begin{array}{l}\text { Not } \\
\text { reported }\end{array}$ & $6 / 12$ both eyes \\
\hline Haritoglou et $a l^{3}$ & 25 & Female & $\begin{array}{l}20 / 500 \text { in both } \\
\text { eyes }\end{array}$ & $\begin{array}{l}\text { Exudative maculopathy, } \\
\text { small haemorrhages } \\
\text { located in the nerve } \\
\text { fiber layer in } \\
\text { both eyes }\end{array}$ & No treatment & 8 weeks & $\begin{array}{l}6 / 60 \text { right eye; } \\
6 / 9.6 \text { left eye }\end{array}$ \\
\hline $\begin{array}{l}\text { Preechawat and } \\
\text { Poonyathalang }\end{array}$ & 20 & Male & $\begin{array}{l}\text { Counting } \\
\text { fingers in } \\
\text { both eyes }\end{array}$ & $\begin{array}{l}\text { Disc hyperaemia } \\
\text { in both eyes; flame } \\
\text { shaped haemorrhage } \\
\text { at fovea in right eye }\end{array}$ & $\begin{array}{l}\text { Intravenous } \\
\text { methylprednisolone } \\
250 \mathrm{mg} \text { four times per } \\
\text { day for } 3 \text { days } \\
\text { followed by oral } \\
\text { prednisolone } 60 \mathrm{mg} / \\
\text { day tapered over } 4 \\
\text { weeks }\end{array}$ & $\begin{array}{l}18 \\
\text { months }\end{array}$ & $6 / 6$ both eyes \\
\hline
\end{tabular}

The exact mechanism of DF-associated optic neuropathy is currently unknown. It is possible the optic disc inflammation may have an immunogenic origin, and thus empirical treatment with high dose steroid appears reasonable, but should be avoided in the stage of acute viraemia.

The clinical course and prognosis of patients with DFassociated optic neuropathy is variable and may range from improvement in visual function with complete visual recovery to optic atrophy and permanent visual loss.

\section{References}

1 Lim WK, Mathur R, Koh A, Yeoh R, Chee SP. Ocular manifestations of dengue fever. Ophthalmology 2004; 111: 2057-2064.

2 Wen KH, Sheu MM, Chung CB, Wang HZ, Chen CW. The ocular fundus findings in dengue fever. [in Chinese]. Gaoxiong Yi Xue Ke Xue Za Zhi 1989; 5: 24-30.

3 Haritoglou C, Dotse SD, Rudolph G. A tourist with dengue fever and visual loss. Lancet 2002; 360: 1070.
4 Preechawat P, Poonyathalang A. Bilateral optic neuritis after dengue viral infection. J Neuroophthalmol 2005; 25: 51-52.

5 Bacsal KE, Chee SP, Cheng CL, Flores JV. Dengue-associated maculopathy. Arch Ophthalmol 2007; 125: 501-510.

6 Haritoglou C, Scholz F, Bialasiewicz A, Klauss V. Ocular manifestation in dengue fever. [in German]. Ophthalmologe 2000; 97: 433-436.

7 Cruz-Villegas V, Berrocal AM, Davis JL. Bilateral choroidal effusions associated with dengue fever. Retina 2003; 23: 576-578.

8 Siqueira RC, Vitral NP, Campos WR, Orefice F, de Moraes Figueiredo LT. Ocular manifestations in dengue fever. Ocul Immunol Inflamm 2004; 12: 323-327.

9 Chlebicki MP, Ang B, Barkham T, Laude A. Retinal hemorrhages in 4 patients with dengue fever. Emerg Infect Dis 2005; 11: 770-772.

10 Nainiwal S, Garg P, Prakash G, Nainiwal N. Bilateral vitreous hemorrhage associated with dengue fever. Eye 2005; 19: 1012-1013.

11 Chan DP, Teoh SC, Tan CS, Nah GK, Rajagopalan R, Prabhakaragupta MK et al. The eye institute dengue-related ophthalmic complications workgroup. Ophthalmic complications of dengue. Emerg Infect Dis 2006; 12: 285-289.

12 Mehta S. Ocular lesions in severe dengue hemorrhagic fever (DHF). J Assoc Physicians India 2005; 53: 656-657. 